\title{
Lusioersily
}

\section{Lidar Investigation of Knockdhu Promontory and its Environs, County Antrim, Northern Ireland}

McNeary, R. WA. (2014). Lidar Investigation of Knockdhu Promontory and its Environs, County Antrim, Northern Ireland. Archaeological Prospection, 21, 263-276. https://doi.org/10.1002/arp.1488

Link to publication record in Ulster University Research Portal

\section{Published in:}

Archaeological Prospection

Publication Status:

Published (in print/issue): 01/01/2014

DOI:

10.1002/arp.1488

\section{Document Version}

Publisher's PDF, also known as Version of record

\section{General rights}

Copyright for the publications made accessible via Ulster University's Research Portal is retained by the author(s) and / or other copyright owners and it is a condition of accessing these publications that users recognise and abide by the legal requirements associated with these rights.

\section{Take down policy}

The Research Portal is Ulster University's institutional repository that provides access to Ulster's research outputs. Every effort has been made to ensure that content in the Research Portal does not infringe any person's rights, or applicable UK laws. If you discover content in the Research Portal that you believe breaches copyright or violates any law, please contact pure-support@ulster.ac.uk. 
Archaeological Prospection

Archaeol. Prospect. 21, 263-276 (2014)

Published online 20 June 2014 in Wiley Online Library

(wileyonlinelibrary.com) DOI: 10.1002/arp.1488

\title{
Lidar Investigation of Knockdhu Promontory and its Environs, County Antrim, Northern Ireland
}

\author{
RORY W. A. MCNEARY* \\ School of Environmental Sciences, University of Ulster, Coleraine, BT52 1SA, Northern Ireland, UK
}

\begin{abstract}
A high-resolution aerial lidar survey (up to 40 points $\mathrm{m}^{-2}$ ) has been carried out in the environs of Knockdhu Promontory in the Antrim Uplands, which is recognized as one of Northern Ireland's most important relict multiperiod archaeological landscapes. This lidar survey was amongst the first such surveys commissioned specifically for archaeological purposes in Northern Ireland and has helped to re-evaluate the archaeological landscape character of a $9 \mathrm{~km}^{2}$ study area and inform future conservation studies. Sampled ground observation was undertaken in an attempt to provide a higher degree of interpretive integrity. These field observation exercises also highlighted the importance of the high vertical resolution of the data $(0.05 \mathrm{~m}$ at $2 \sigma(95 \%$ confidence level)) in delineating extremely subtle upstanding earthwork features that had hitherto gone unnoticed. Much of the archaeological evidence identified can be broadly ascribed to the early post-medieval period (AD 1599-1750); this includes field boundaries, cultivation furrows, enclosures, transhumance huts, abandoned settlements and associated pathways, but the higher ground of the Antrim Plateau in this locality is also characterized by evidence of prehistoric activities and substantial earthworks survive such as the 'Linford Barrows' and 'Knockdhu Promontory Fort'. The lidar study has identified as many as 285 previously unrecorded potential archaeological sites and amended existing records within the Northern Ireland Sites and Monuments Record (NISMR) and has proved transformational as a technique to 'open up' the Ulster uplands for archaeological study. Copyright (C) 2014 John Wiley \& Sons, Ltd.
\end{abstract}

Key words: aerial archaeology; airborne laser scanning (ALS); geographical information systems (GIS); ground observation; Knockdhu; lidar

\section{Introduction}

'Knockdhu' ('Black Mountain' in Gaelic) is the name given to a headland that commands views of the coastal plain, from Larne to Ballygalley, and across the North Channel to Scotland (Figure 1). The site comprises a triple rampart inland promontory fort, and excavations undertaken in 2008 dated the site to the Late Bronze Age, roughly 3000 years ago (Macdonald, 2010). Although these excavations shed new light on the promontory itself, a true appreciation and understanding of the surrounding landscape was still felt to be lacking by archaeologists within the Northern Ireland Environment Agency (NIEA). Inspired by the results achieved by the FLI-MAP lidar survey of the Hill of Tara, County Meath, undertaken by The Discovery Programme (Corns et al., 2008; Corns and Shaw, 2009),

\footnotetext{
* Correspondence to: R. W. A. McNeary, School of Environmental Sciences, University of Ulster, Coleraine, BT52 1SA, Northern Ireland, UK.

E-mail: r.mcneary@ulster.ac.uk
}

the NIEA commissioned Fugro-BKS Ltd in 2009 to carry out a similar survey in the environs of Knockdhu promontory, so as to afford greater insight into a recognized relict archaeological landscape and facilitate improved cultural heritage management (CHM).

\section{Geographical context}

The study site is located in northeast County Antrim in Northern Ireland and is represented by a $9 \mathrm{~km}^{2}$ area of lidar coverage, which includes the townland of Drains Bog and partly encompasses the townlands of Ballycoos, Ballygawn, Ballyhackett, Ballyruther, Ballywillin, Corkermain, Dunteige, Linford, Loughduff and Sallagh (Figure 2). A townland is a small landholding unit and the legacy of a medieval landscape assessment system (see McErlean, 1983, pp. 315-316; Nicholls, 2003, pp. 97-100; Smyth, 2006, p. 76). The lidar takes in an upland zone (Antrim plateau) and a lowland zone (the coastal strip), but the area of archaeological interest is very much focused on the transitional zone 


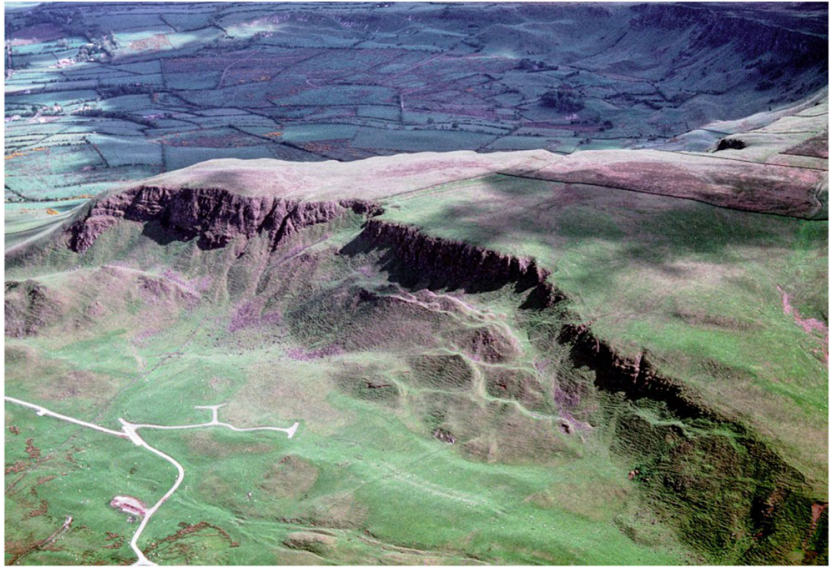

Figure 1. Oblique aerial view of Knockdhu promontory (source: NIEA, Built Heritage). This figure is available in colour online at wileyonlinelibrary.com/journal/arp

and the uplands themselves, where relict feature survival is highest and agricultural improvement and modern ploughing has had less impact on rates of survival. The uplands are characterized by a series of basalt plateau, which include the Knockdhu promontory. The study area is dominated by open pasture, with limited arable cultivation and woodland. The exposed summits are generally covered by tussocky moorland grasses and, in places, bracken where sheep grazing is the major land use. The low-lying eastern side of the study area is dominated by small and regular pasture fields and isolated farmsteads nestling in sheltered sites towards the foot of the slopes.

\section{Previous archaeological research}

Archaeological research in the study area has been primarily concerned with creating a baseline record of the archaeology for heritage management purposes. This archaeological survey work has been continued at different times over the past three decades by small teams of NIEA survey staff. Two of the most significant pieces of research outside of this government-led survey work have been Richard Hodges's interpretive overview of relict earthwork remains based on fieldwork he carried out in 1973 (Hodges, 1975) and the investigations undertaken by Queen's University Belfast (QUB) in 2008, which focused on Knockdhu promontory fort and formed the subject of a Time Team television programme broadcast in 2009 (see Macdonald, 2010). Despite this past work, little systematic earthwork mapping has been undertaken in the study area.

\section{Methodology}

\section{Data integration}

A geographical information systems (GIS) project was created to provide a platform for co-registering existing datasets, both historical and modern, with the acquired lidar data for the study area. Contemporary vector product, orthophotography and georeferenced historical mapping dating from the 1830 s were added. In addition, digital historic environment records from the NIEA and high-resolution $(0.1 \mathrm{~m})$ vertical aerial orthophotography, also generated by Fugro-BKS Ltd in 2009, were incorporated into the project.

\section{The lidar survey}

The lidar survey was carried out by Fugro-BKS Ltd on behalf of the NIEA in July 2009 using a helicoptermounted laser mapping sensor (FLI-MAP 400 system). The average point density of the dataset was requested at approximately 40 points $\mathrm{m}^{-2}$. In general this density was met but due to the very hilly terrain and strong winds encountered during the survey some parts of the study area were covered at a slightly lower density (30-38 points $\mathrm{m}^{-2}$; FugroBKS Ltd, 2009). The ground-sampling distance was specified by archaeologists from NIEA and their decision was again influenced by the quality of the imagery produced from similar specified surveys in the Republic of Ireland.

The relative merits of such high-resolution surveys versus traditional ground-based surveys in terms of cost and accuracy have been discussed in the literature (see Shaw and Corns, 2011, pp. 77-86). It is generally accepted that higher resolution lidar surveys do show a much greater degree of detail than coarser lidar surveys (Crutchley, 2010, pp. 15-16), and the higher accuracy of the FLI-MAP system in the z-field compared with other systems also allows more readily the detection of microtopographic features (Anthony Corns, pers. comm. 2013). These higher resolution surveys, however, come at the price of generally much smaller areas being flown due to the financial cost and it is widely believed that $0.5 \mathrm{~m}$ to $1 \mathrm{~m}$ ground resolution is often adequate to record most features of interest (Crutchley, 2010, pp. 15-16). By aggregating with random cells it is possible to simulate coarser lidar-data acquisition for a sample area from the study site and note a recognizable degradation in clarity in the imagery with less than $0.5 \mathrm{~m}$ resolution (Figure 3). In truth, however, there is little or no feature definition lost between the $0.25 \mathrm{~m}$ and $0.125 \mathrm{~m}$ resolution 

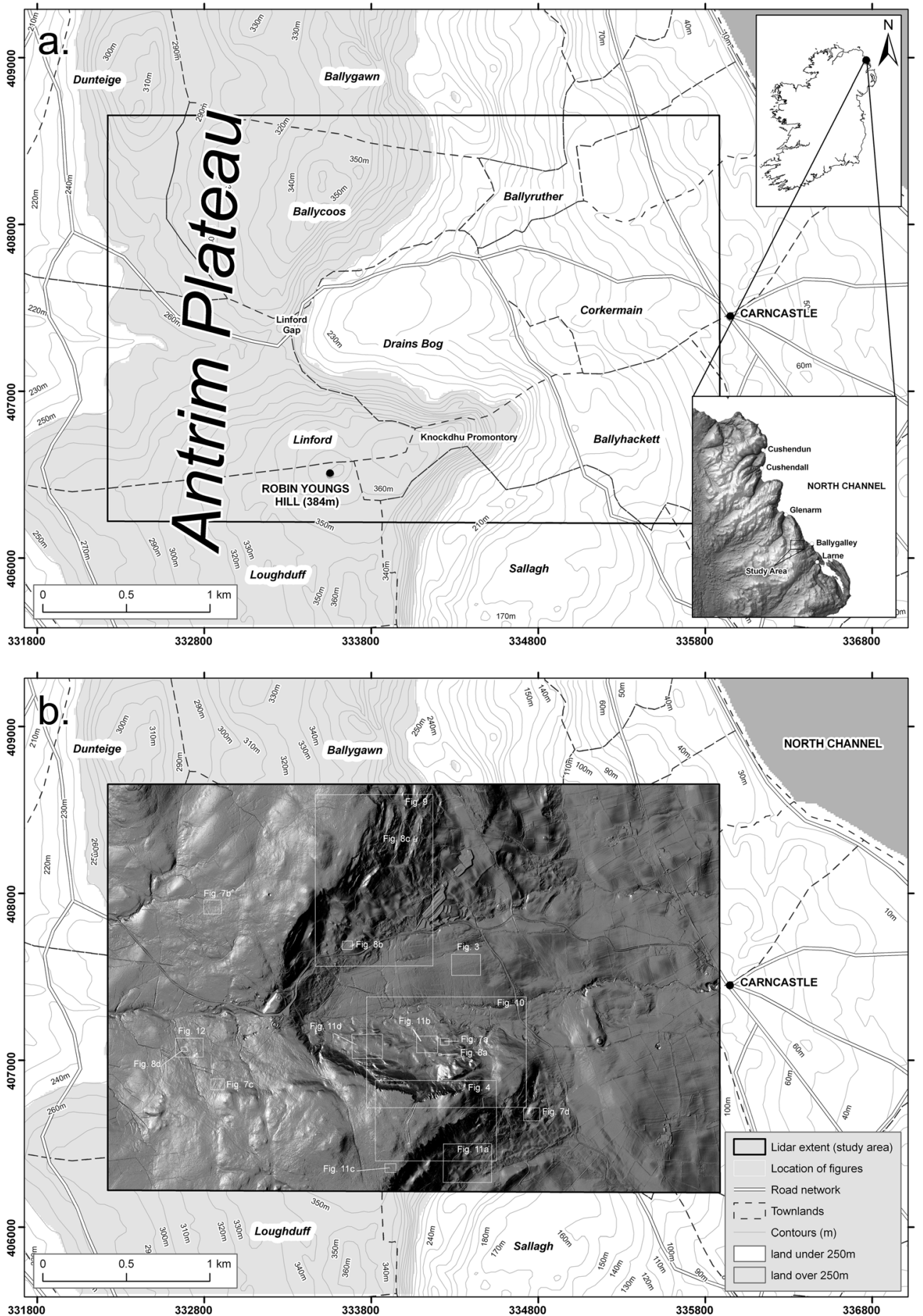

Figure 2. (a) Location of study area showing relief and townland boundaries. (b) Extent of lidar survey (hillshade) and location of figures.

imagery in this particular instance and the most recent NIEA lidar surveys to be commissioned for archaeological purposes are now being captured at a ground resolution of $0.25 \mathrm{~m}$ (Claire Foley, pers. comm. 2013).
Lidar visualization, digital transcription and analysis

For this study two principal techniques, hill-shading and local-relief modelling (Hesse, 2010), were used for the visualization and analysis of the airborne lidar 

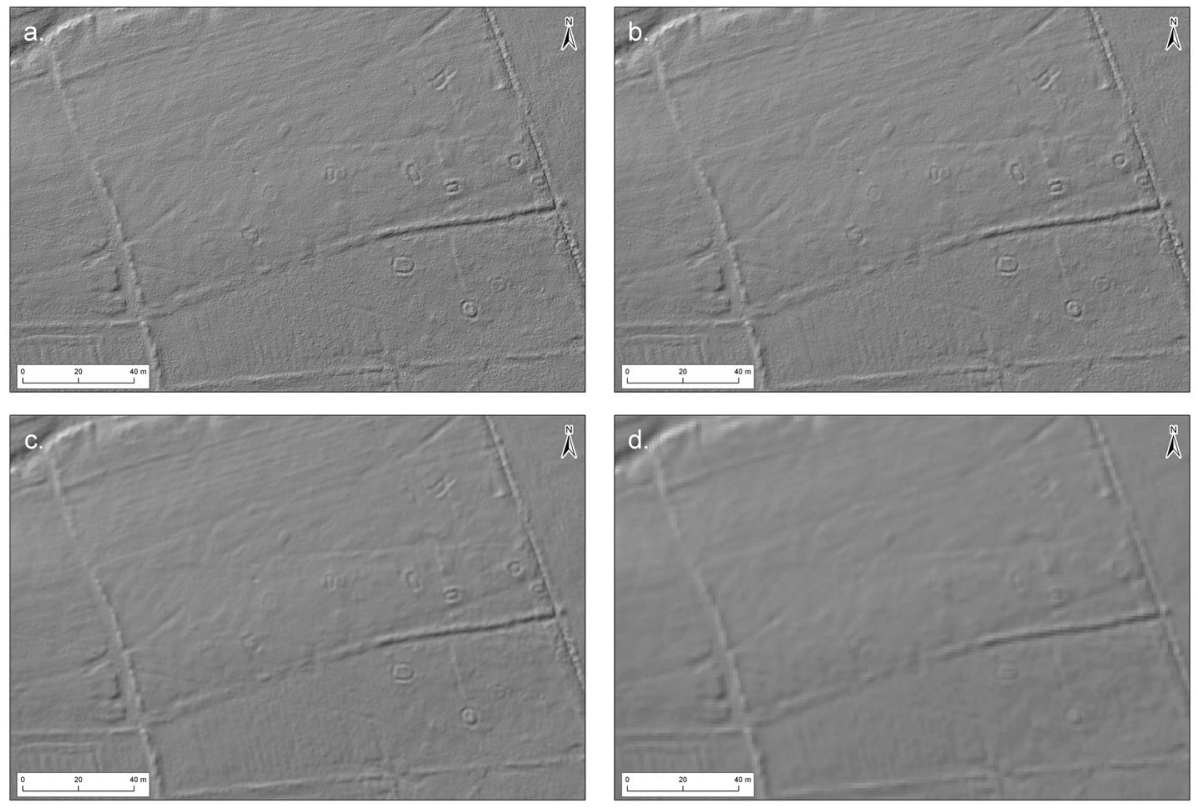

Figure 3. Archaeological features (SMR No. ANT035:066), extract of the site visualized with standard hillshade. Digital elevation models with grid sizes (a) $0.125 \mathrm{~m}$, (b) $0.25 \mathrm{~m}$, (c) $0.5 \mathrm{~m}$ and (d) $1 \mathrm{~m}$ are shown. Aggregating with random cells simulates coarser lidar-data acquisition.

elevation data. For digital transcription of archaeological features, both established and previously unrecorded, the local-relief modelling technique proved to be the most expedient as there is negligible horizontal shift in the position of positive and negative features (Bennett et al., 2012, p. 45). In this case the local relief model (LRM) was derived by resampling the original digital elevation model (DEM; $0.125 \mathrm{~m}$ ) to a lower resolution of $5 \mathrm{~m}$ (the trend $\mathrm{DEM}$ ), which was then subtracted from the original DEM. This procedure separates local small-scale features from large-scale landscape forms (Štular et al., 2012, p. 3356). This visualization was given context by comparing other raster visualization techniques (for an overview of these techniques see Devereux et al., 2008; Challis et al., 2011; Bennett et al., 2012; Štular et al., 2012), aerial observation from recent vertical orthophotographs and nineteenth and twentieth century historic maps.

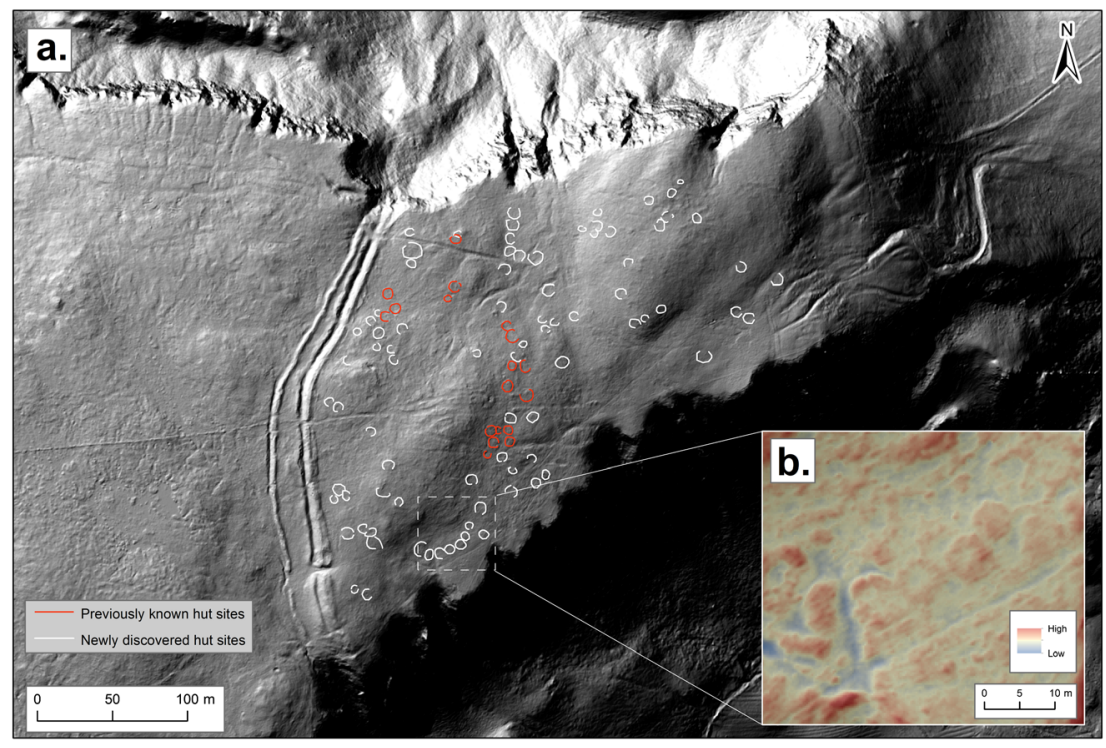

Figure 4. (a) Hut sites on Knockdhu promontory as identified from lidar analysis (hillshade) compared with number previously known. (b) Detailed view of huts (hillshade with local-relief model at $50 \%$ transparency overlain). This figure is available in colour online at wileyonlinelibrary.com/ journal/arp 
Three-dimensional visualizations were also created in order to provide further perspective.

The starting point for the archaeological analysis of the lidar was the existing NISMR database held by the NIEA. This database contains entries derived from field survey, excavations, published research, aerial photographs, historical documents and maps. In the first instance this record was cross-referenced with the lidar and for each recorded site a proforma was filled in. This proforma was based on the current NISMR entries as they appear online (see http:// apps.ehsni.gov.uk/ambit/Default.aspx). In addition, a note of any positional disparity between the recorded grid reference in the NISMR and the actual position of the site as it appeared on the lidar was made. Any new potential archaeological sites revealed by the lidar analysis were digitized, and descriptive information and any interpretations entered into a linked GIS database.

\section{The field survey method}

The project used a traditional two-stage approach of deskbased assessment and feature transcription followed by sampled ground observation to confirm the accuracy of the desk-based interpretation and mapping (see e.g. Hoyle, 2005, 2011; Crutchley, 2010, 2013). Field visits
Table 1. Numbers of newly mapped potential archaeological features classified into broad categories.

\begin{tabular}{lc}
\hline Category of site & Number of sites \\
\hline Hut site & 167 \\
Enclosure & 40 \\
Structure & 33 \\
Quarry & 25 \\
House site & 15 \\
Other & 5 \\
\hline
\end{tabular}

to the study area took place in May 2013 and 100 potential archaeological features were checked in the field. A variety of site types were chosen but with a bias towards potential settlement remains, as the author was keen to explore further the potential for medieval rural settlement survival in this landscape, the evidence for which is limited within the context of research in Irish archaeology as a whole (Barry, 2009 , p. viii), and future research will target relict settlement remains for detailed field analysis.

The fieldwork allowed for a number of potential sites to be discounted as non-sites. For example, first analysis of the lidar had identified a great number of small pits with associated spoil on the slopes immediately below and to the northeast of the Linford Gap. These were thought to be perhaps the remains of flint quarrying; on visiting this area it was realized from a

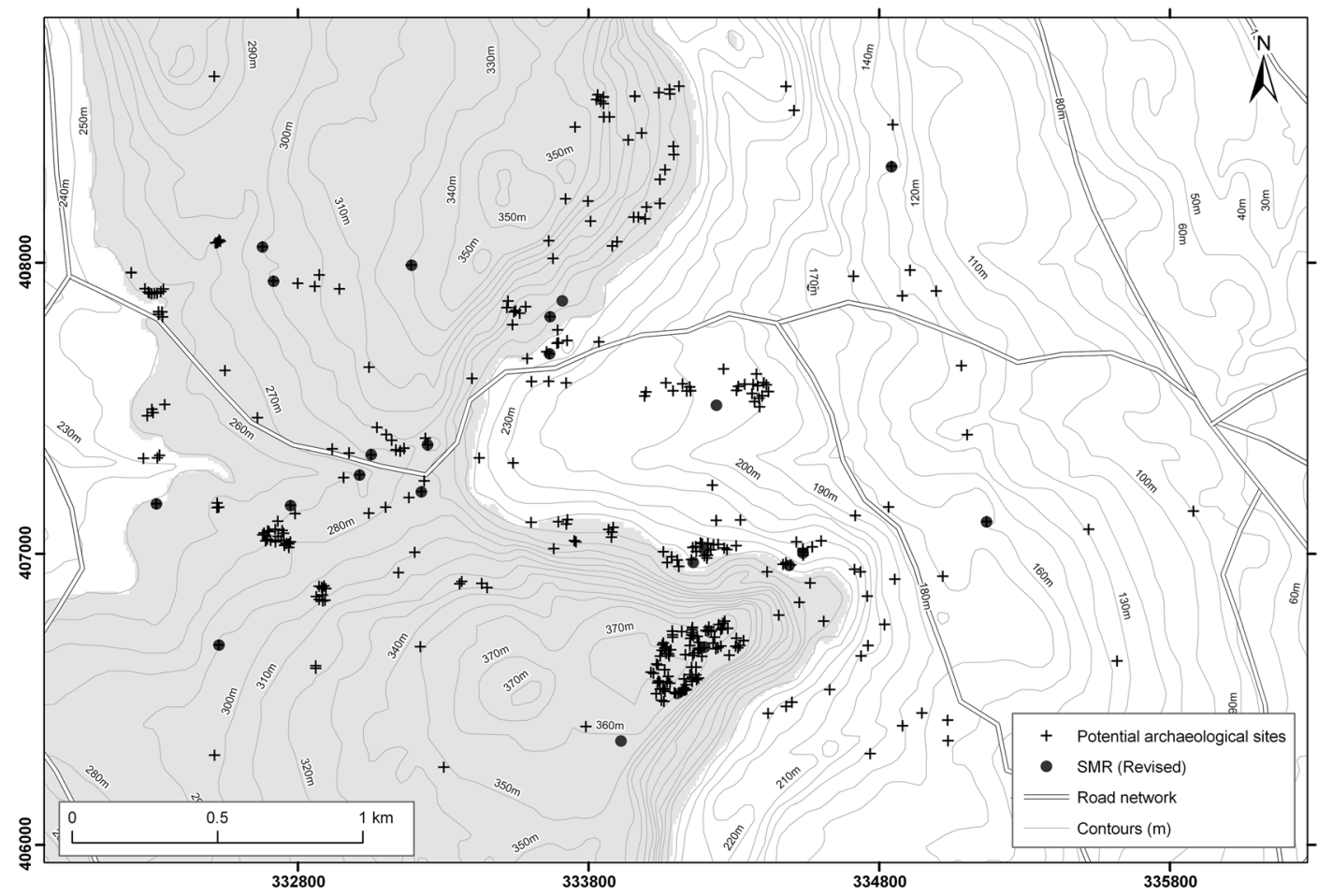

Figure 5. Distribution of potential archaeological features. 


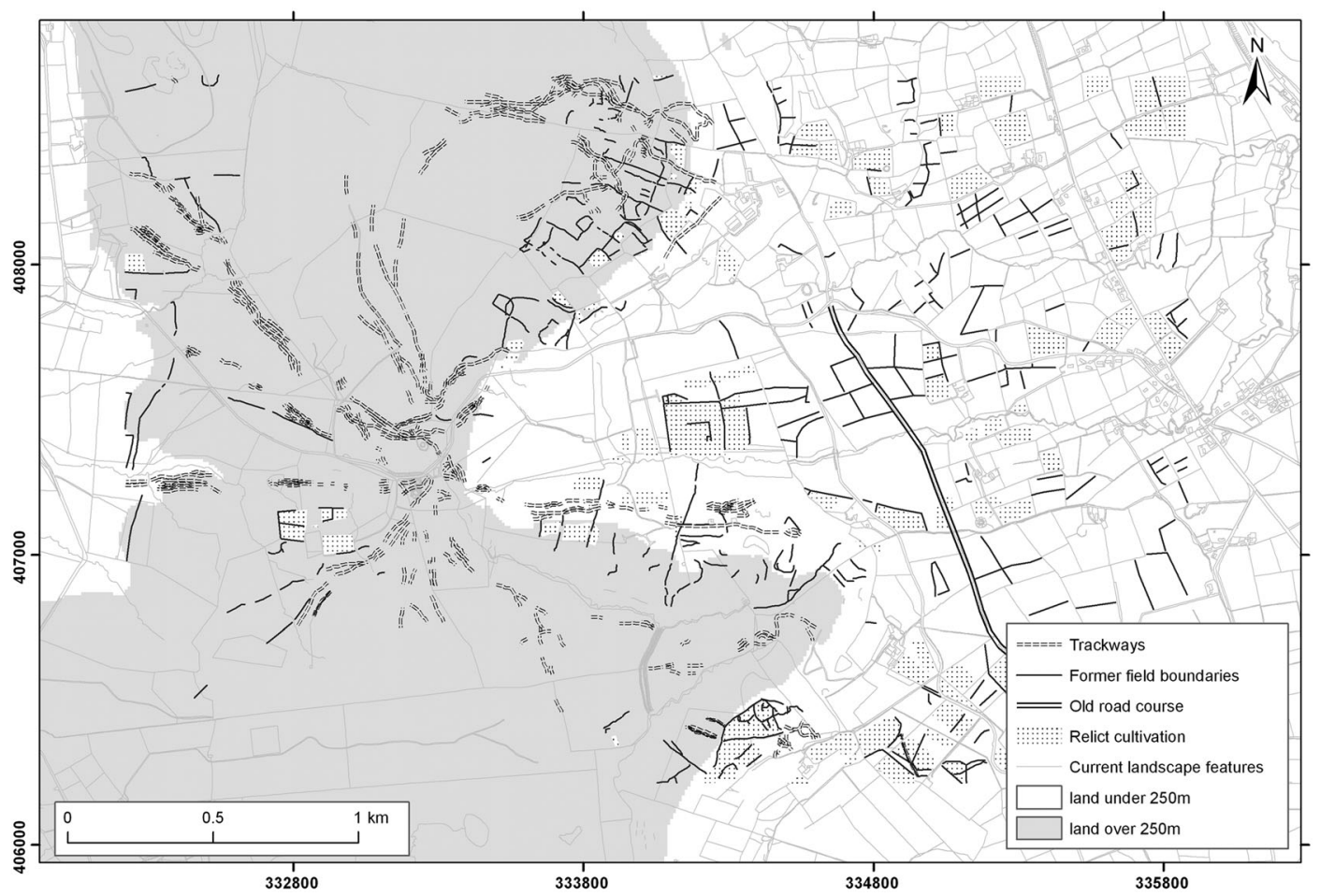

Figure 6. Distribution of trackways, former field boundaries and areas of relict cultivation.

visual inspection that these features were not anthropogenic but areas of natural slippage, which allowed for the removal of 36 of these sites from the project database. For the most part, however, the field visits confirmed the results of the lidar analysis, helped to clarify the nature of features in the field and led to further incidental discoveries, such as a potentially in situ scatter of flint knapping debitage; a type of site that would most definitely not be observed on lidar.

The results of the field validation exercise were fed back into overall analyses of the original datasets and allowed for a quality assessment of the lidar-based prospection.

\section{Results}

\section{Improving the known record}

The current NISMR lists 42 archaeological monuments, ranging from areas of neolithic (ca. 4500-2500 BC) flint working to post-medieval (ca. AD 1599-1960) settlements and field systems. Eleven of these monuments are considered of especial importance and are scheduled; these scheduled monuments include the Linford earthworks, the promontory fort at Knockdhu and an
Anglo-Norman (ca. AD 1170-1270) motte in Corkermain townland. The desk-based analysis revealed that 19 of the original 42 recorded sites were not discernible on the lidar. This may have been due to the fact that a site had been subsequently destroyed, its existence based on a documentary reference (rather than field evidence) or the feature was too small, for example, a wayside marker, or a subterranean feature, such as a souterrain; but, in 13 cases the lack of detailed field recording (and the suspected positional inaccuracy of the given grid coordinate) made it difficult to marry the given description in the NISMR with any apparent features in the immediate locality on the lidar. Of the remaining 23 sites identified a further 12 had notable positional

Table 2. Frequency of hut widths occurring amongst those newly mapped during the course of the lidar project.

\begin{tabular}{lc}
\hline Internal hut width $(\mathrm{m})$ & Frequency \\
\hline $0.5-1.4$ & 1 \\
$1.5-2.0$ & 8 \\
$2.1-2.9$ & 52 \\
$3.0-3.9$ & 41 \\
$4.0-4.9$ & 32 \\
$5.0-5.9$ & 22 \\
$6.0-6.9$ & 7 \\
$\geq 7$ & 4 \\
\hline
\end{tabular}


inaccuracies (ranging from $13 \mathrm{~m}$ to $57 \mathrm{~m}$ ), but it was possible to match the site in the database to a signature on the lidar based on the sketches and descriptive notes contained in the SMR file. Given that the NISMR is a curatorial tool for the management and protection of cultural heritage this inaccuracy would potentially have serious ramifications in a planning and development context.

The lidar analysis has allowed for the correction of these positional errors; the accurate mapping of more complex and spatially extensive features, such as field boundaries and trackways, that have up until now been recorded only as a point in the NISMR; and revealed further insights into the already recorded monuments in this landscape. For example, the lidar analysis has allowed for the digitizing of 104 potential hut sites on Knockdhu promontory, whereas before only 18 were recorded (Figure 4).

\section{New discoveries: augmenting the record}

In total 373 'potential archaeological features' were mapped during the course of the lidar desk-based study. At least $285(76 \%)$ are not recorded in the current NISMR (Figure 5). A breakdown of these sites, classified into broad categories, is presented in Table 1.
This breakdown of potentially new archaeological features does not include the numerous braided trackways (ca. $23.5 \mathrm{~km}$ ), former field boundaries (ca. $29.4 \mathrm{~km}$ ) and areas of relict cultivation (ca. $50 \mathrm{ha}$ ) also recorded from the lidar data; features that previously had only ever been recorded incidentally in the NISMR as point locations (rather than polylines and polygons), and in only a very few instances (see Figure 6). Hut sites represent the predominant site type defined by the lidar data $(59 \%)$, followed by enclosures $(14 \%)$ and less determinable features classified as 'structures' (12\%). Structures may include further hut or house sites, small animal folds, clearance cairns and other small mounds, but cannot be categorized with the same level of certainty. Hut and house sites have been differentiated based on plan-shape. Roundhouses have been described as 'hut sites' and oval-shaped (rounded rectangular) and/or rectangular-shaped structures have been described as 'house sites' (after Gardiner, 2012).

The usage of the advisory term 'potential archaeological features' rather than 'archaeological site' follows Hesse (2013), as this study encountered similar issues with regard to 'lack of chronological control'; 'scale', that is, differentiating between discrete features versus sites comprising of interrelated sets of features
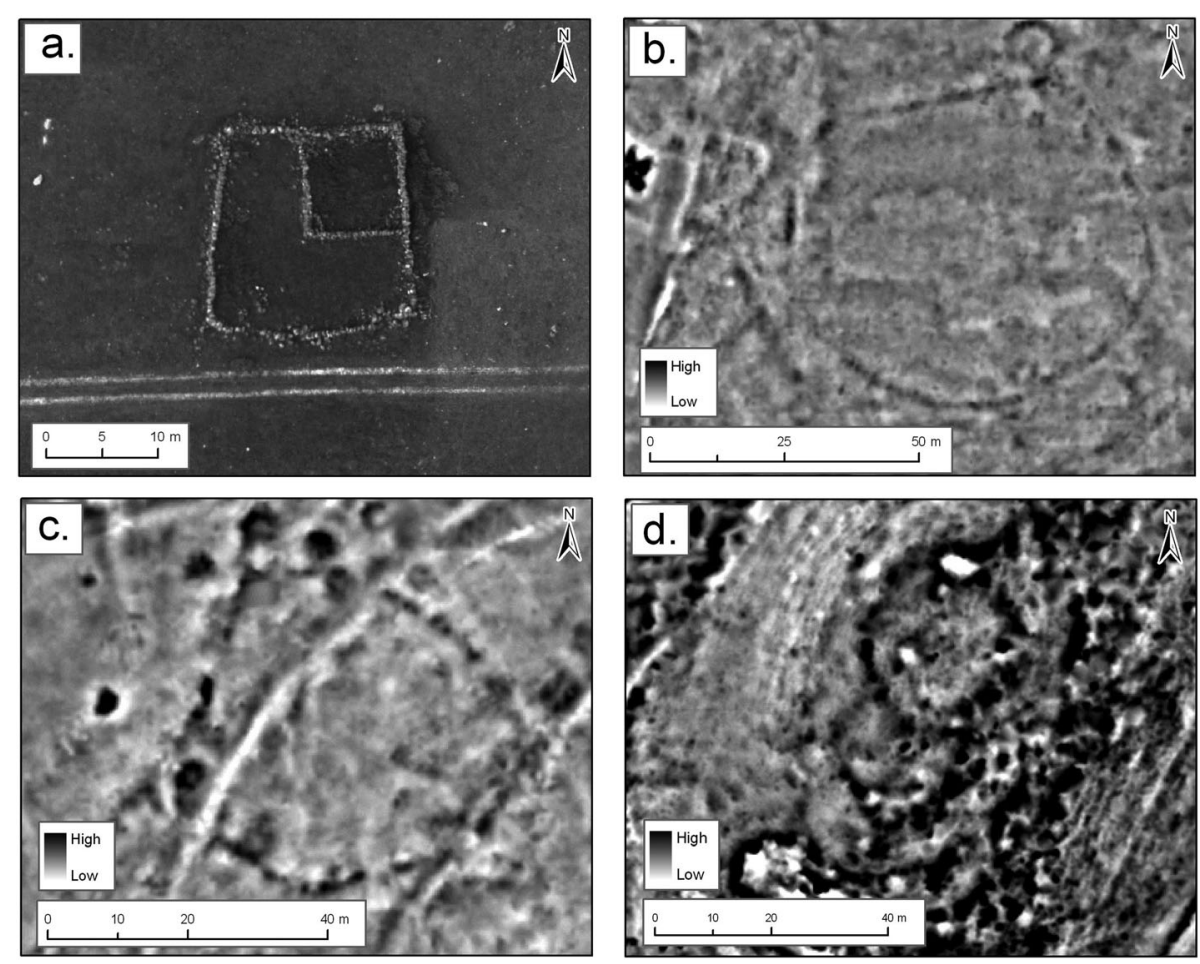

Figure 7. Examples of enclosure types found in the study area: (a) small stone-built sheepfold (vertical aerial photograph); (b) large circular enclosure or corral (local-relief model, LRM); (c) circular enclosure associated with settlement remains (LRM); (d) possible conjoined enclosure (LRM). 

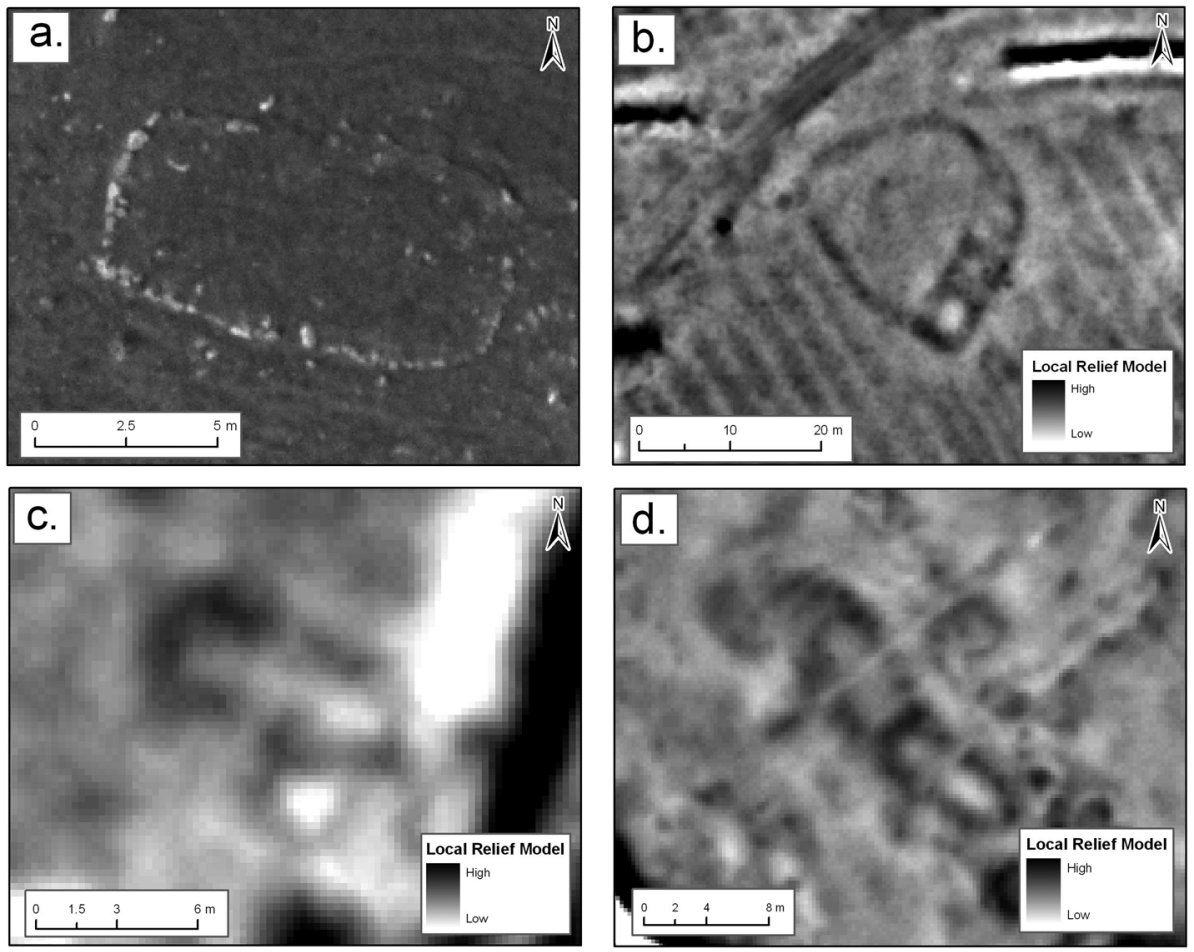

Figure 8. Examples of house sites found in the study area: (a) ovoid house site in Drains Bog townland associated with herding activities (vertical aerial photograph); (b) subrectangular house site and associated yard in Ballycoos townland and associated with infield-outfield mixed farming (local-relief model; LRM); (c) subrectangular house with annex in Ballycoos townland, located above the head-dyke (LRM); (d) two-celled longhouse located on the plateau in Linford townland and associated with a circular enclosure and hut sites (LRM).

and the propensity of perceived 'no or low heritage value sites', such as, post-medieval cultivation ridges, field boundaries and quarries (see Hesse, 2013, p. 177). The following examples (hut sites, enclosures, house sites, field boundaries, cultivation and trackways) will give an impression of the diversity of archaeological sites detected principally from the lidar analysis.

\section{Hut sites}

The majority of the newly discovered hut sites (86\%) are found on the open ground of the plateau itself, and of these $60 \%$ relate to the settlement on Knockdhu promontory, while the remainder are found singly, in loose groupings and lying inside (and sometimes abutting) circular and subcircular walled compounds (similar in many respects to settlement evidence being discovered on the Garron plateau, also in the Antrim uplands; see Gardiner, 2012). Table 2 shows the frequency distribution of internal hut widths $(\mathrm{m})$ for the newly discovered hut sites in the study area. The predominance of narrow internal widths, outside of Knockdhu promontory, suggests that the majority of these huts were never more than temporary structures associated with seasonal herding activities.

\section{Enclosures}

The enclosures identified from the desk-based study are largely located on the plateau summit (37.5\%), and/or on the slopes immediately below (50\%). They range in size from the small $5 \mathrm{~m}^{2}$ stone-built sheepfolds (Figure 7a), a great many of which are marked on the OS maps of the nineteenth century, and which tend to be square in plan, to the larger circular enclosures found on the plateau summit, the largest of which has an internal area of ca. 0.18 ha (Figure $7 \mathrm{~b}$ ). Two of these larger circular enclosures on the plateau are found in proximity to concentrations of hut sites and probably served as overnight enclosures for livestock (see Figure 7c by way of example).

Given the location of these enclosures, on or close to the plateau, it is proposed that the majority of these features relate to livestock management and served as folds or corrals. There are, however, a couple of notable exceptions, including a possible conjoined enclosure (Figure 7d) situated on a raised knoll ca. $340 \mathrm{~m}$ to the east of Knockdhu promontory, which may have served as a free-standing gateway bastion controlling the most direct-approach to the promontory. 


\section{House sites}

Thirty-five house sites are interpreted on the lidar data. Twenty-one of these have previously been recorded and $95 \%$ of these house sites can be associated with the prominent clustered settlement in Drains Bog townland and first described by Hodges (1975, p. 22) as follows:

On a N-facing spur beneath the N. cliff of Knockdhu are ten elliptically shaped structures...Their walls are two-stones thick and $2 \mathrm{ft}$ across, and there is regularly one entrance about $2 \mathrm{ft}$ wide. This must be the summer settlement of a group of shepherds or cattle-herders working on the top of the Sallagh Braes.

An example of one of these house sites is provided in Figure 8a. A further recorded house site, situated at the juncture between Drains Bog and Ballycoos townland, is subrectangular in plan with an associated ovoid yard, see Figure $8 \mathrm{~b}$. This house site, along with six other newly

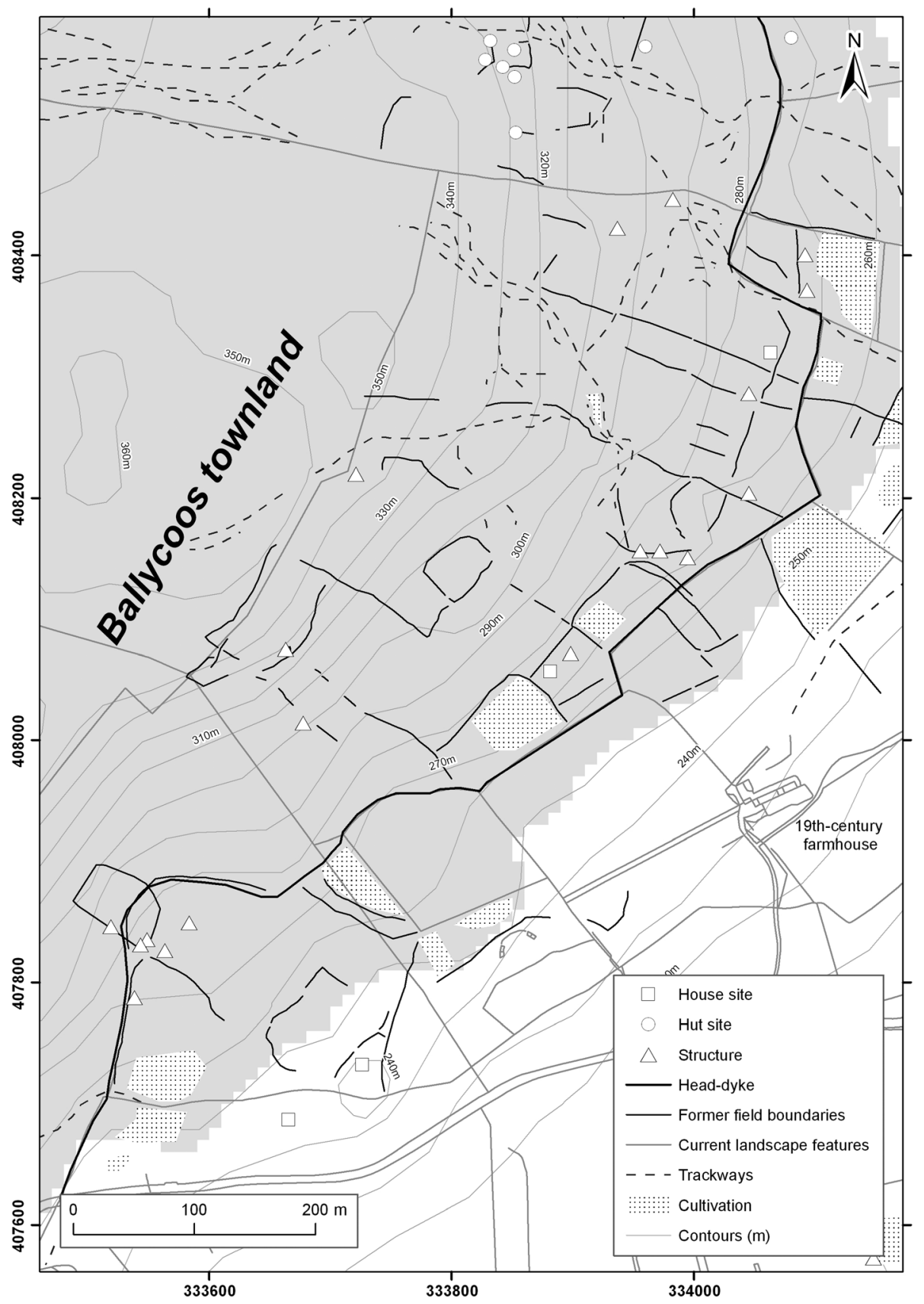

Figure 9. Relict landscape features in Ballycoos townland. 
discovered sites, can be associated with a more settled farming community operating an infield-outfield system on the slopes below the plateau in Ballycoos townland (see Figure $8 \mathrm{c}$ for an example of one of these newly imaged house sites). The remaining newly discovered house sites are for the most part outliers associated with these two concentrations, however, three house sites appear on the plateau itself. One is located in isolation at the western limits of the study area; a second twocelled longhouse (Figure 8d) is associated with a circular enclosure and hut sites, while the third is situated $10 \mathrm{~m}$ to the north of the prominent prehistoric cairn that stands overlooking the Linford Gap.

\section{Field boundaries}

The former field boundaries identified from the lidar data predominate $(63 \%)$ in the eastern half of the study area, where land enclosure is more pronounced than the largely open upland. These former boundaries represent the remains of post-medieval field boundaries (as depicted in the OS maps of the nineteenth century) that have been systematically removed from the 1940s onwards to accommodate new and more intensive farming regimes (such as silage monoculture) over hay-making and small-scale rotational cropping.
Outside of this pattern of field boundary removal exists two notable concentrations of relict field boundaries associated with the farm settlements in Ballycoos (Figure 9) and Drains Bog townland (Figure 10). The former field boundaries in Ballycoos relate to an early post-medieval infield-outfield model of farming that can be associated with a small number of farm units as marked on the OS maps of the nineteenth century. The field boundaries form part of a coherent system of fields that demark both property division and modes of farming activity in terms of grazing and cultivation. In contrast the relict field boundaries in Drains Bog townland are associated with a stock-focused farming zone.

\section{Cultivation}

The relict cultivation remains, like the former field boundaries identified, predominate in the eastern half of the study area on the better drained soils of the lower-lying coastal strip (62\%). These cultivation remains also respect the post-medieval field pattern depicted on the OS maps of the nineteenth century and can be associated with arable farming and pasture reseeding in the eighteenth to twentieth centuries. Outside of this pattern there is evidence for cultivation occurring on the lower slopes of the plateau in

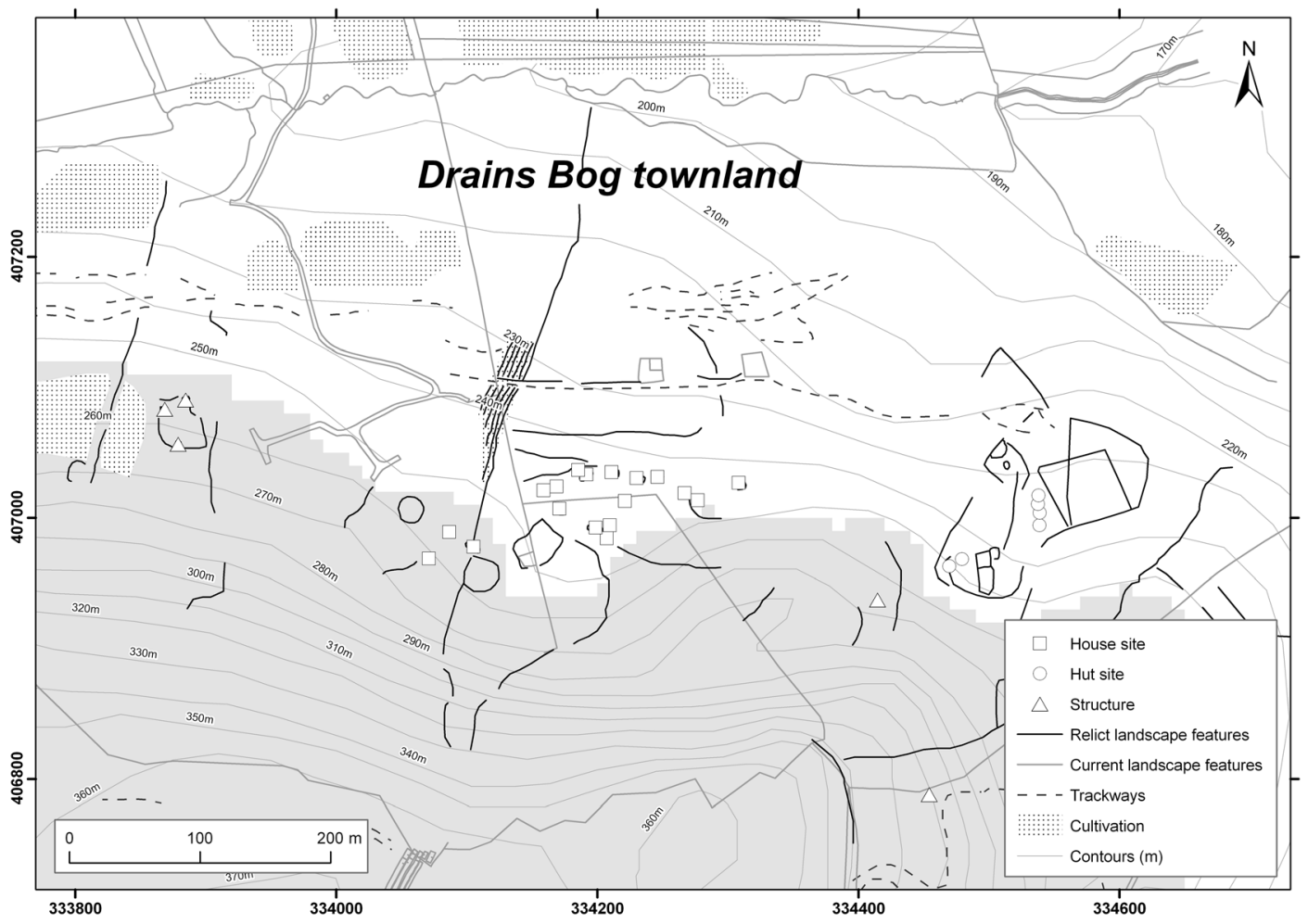

Figure 10. Relict landscape features in Drains Bog townland. 

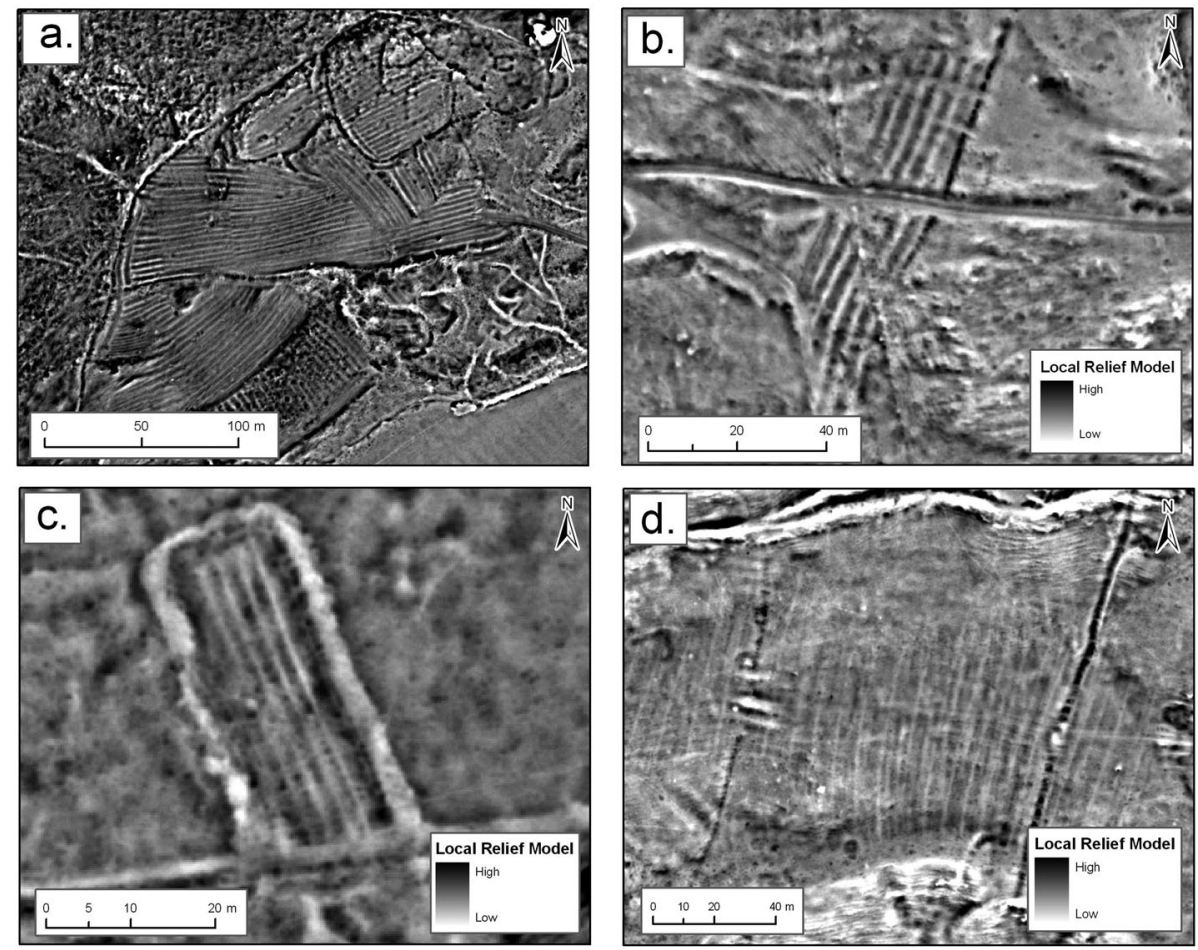

Figure 11. Examples of cultivation remains in the study area: (a) nineteenth century tillage in the vicinity of a post-medieval farmstead in Sallagh townland (local-relief model; LRM); (b) cultivation associated with herders' huts in Drains Bog townland (LRM); (c) spade-dug potato garden located on the plateau in Ballyhackett townland (LRM); (d) possible prehistoric cultivation distinguished by its very narrow ridge and furrow (LRM).

Ballycoos, Drains Bog and Sallagh townlands; some limited evidence on the plateau itself and on the low-lying ground at the centre of the study area. This cultivation evidence reflects: short-lived periods of tillage expansion and contraction in the nineteenth century (Figure 11a); supplementary arable production carried out in conjunction with seasonal dairying activities (Figure 11b); as well as examples of small-scale spade-dug cultivation plots associated with house and/ or hut sites (Figure 11c). There are some possible examples of much earlier cultivation based on the ephemeral nature of the remains and the very narrow ridge and furrow (Figure 11d).

\section{Trackways}

The cartographic evidence reveals that before the OS 6-inch map of 1853-1858 there was no formal road giving access to this part of the plateau or the hinterland beyond; although a series of footpaths, or trackways, are marked on this edition and later maps. The modern road from Carncastle to Feystown was laid out sometime between the OS 6-inch map of 1853-1858 and the 1903-1906 map edition. Before the construction of this road, access to the plateau was provided by two distinctive concentrations of trackways, and for the first time the lidar has allowed for these braided tracks to be accurately mapped (see Figure 6).

\section{Discussion}

The new archaeological discoveries made during the course of this project include various categories of evidence, such as, hut sites, boundaries, trackways, enclosures and cultivation ridges. These relict features must have worked as a farming system, albeit one that was flexible and capable of change, reflective of the vagaries of settlement contraction and expansion over the centuries as a result of economic and/or climatic factors, changing modes of farming and landlord-driven 'improvements'. Most of the remains discussed are linked in some way to the past utilization of this landscape for agricultural purposes and can conservatively be associated with a terminus ante quem sometime in the early post-medieval period. The high level of feature survival in the areas immediately below the plateau is reflective of them having been left largely unaffected and untouched by the more mechanized farming practiced increasingly after the 1940s and evidenced on the lower lying coastal strip in terms of pasture reseeding and field consolidation. 
While there are vestiges of these agricultural remains portrayed on the OS maps of the nineteenth century and early twentieth century the majority of these relict features pre-date the earliest OS cartography commissioned in the 1830s and thus have the potential to provide important insights into the evolution, changing nature and demise of this farming landscape in preceding centuries and offer a window on farming practice and settlement in the late medieval and early post-medieval periods.

The newly identified potential hut sites identified above $250 \mathrm{~m}$ above OD point to the very real possibility of medieval (ca. AD 400-1599) and prehistoric (ca. 4500 $\mathrm{BC}-\mathrm{AD}$ 400) components encompassed in this relict farming landscape. Aside from the hut sites on the promontory, which can be presumed to date to the Bronze Age (ca. 2200-500 BC) based on recent excavation evidence (see Macdonald, 2010), the remaining hut sites identified might also be relics of the warmer and drier climates of the Early (ca. 2200-1600 BC) and Middle (ca. 1600-1200 BC) Bronze Age, or alternatively herders' huts associated with the practice of booleying (transhumance) in the medieval and early post-medieval periods. These huts sites may have fallen out of use as the direct consequence of cattle being replaced by sheep, as the preferred stock type of the upland farmer, from the seventeenth century onwards (Rathbone, 2009, p. 123). Sheep tend to need less supervision than cattle and therefore the necessity of overnighting with livestock on the upland would have been removed (Evans, 1940, p. 178; Rathbone, 2009, p 123). Regardless of their chronology, the hut sites, outside of those contained within Knockdhu promontory itself, are most likely the shelters of herders and point to the fact that this upland was part and parcel of a farming system

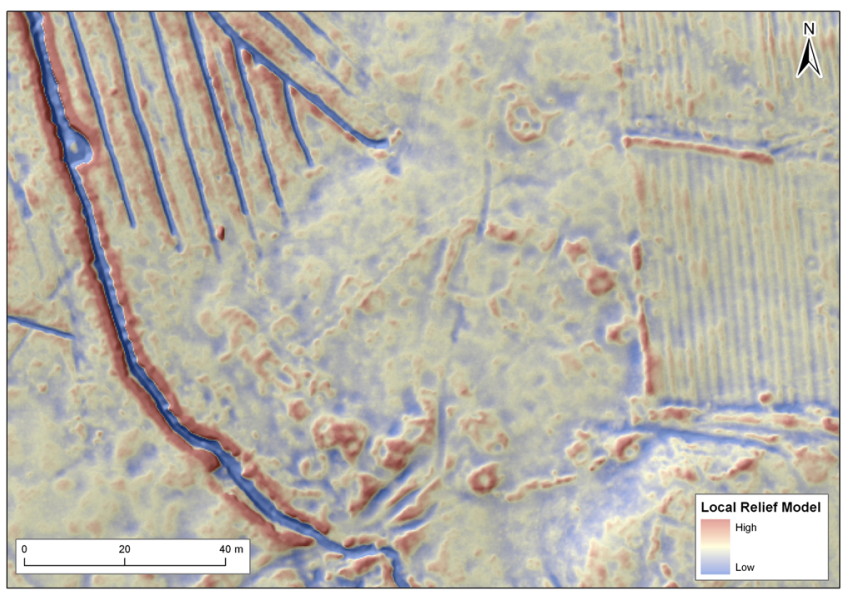

Figure 12. Evidence of arterial drainage, at NW of image, encroaching upon previously unrecorded archaeological remains' (hillshade with LRM at $50 \%$ transparency overlain). This figure is available in colour online at wileyonlinelibrary.com/journal/arp that involved the communal exploitation of pastures on the plateau by kin-groups more permanently settled on the foothills below the plateau.

\section{Conclusions}

The results presented in this paper demonstrate the utility of low-altitude high point-density lidar survey for the examination of open-pasture upland landscapes containing extensive low-relief earthworks. These archaeological landscapes have hitherto proven difficult to survey and readily understand without intensive campaigns of fieldwork. The lidar-based desktop assessment has allowed for a major overhaul and critique of the existing NISMR; the accurate mapping of more complex and spatially extensive features; and the generation of new archaeological information that can be added to the record and applied to improve the cultural historic understanding of this landscape and others like it across the Antrim plateau. Lidar should, therefore, be considered as a first-choice dataset for desk-based interpretation and mapping exercises in advance of future fieldwork in these types of uplands.

The lidar visualization technique of local relief modelling proved to be most useful, both as a means of prospecting for subtle low-relief earthworks and also for facilitating expedient and accurate vector digitizing. It clearly identified positive and negative features in both low- and high-relief landscapes within the study area, and even subtle earthworks, such as cultivation ridges, could be readily delineated and digitized. Sampled field verification exercises were also worthwhile, allowing for false monument detections to be eliminated and observations to be made about the archaeological landscape that go beyond the limitations of remotely sensed data, and which reinforce the necessity of a dual approach, incorporating both desk- and field-based studies, in the analysis of archaeological landscapes. Perhaps the greatest revelation to the field team was just how subtle some of the earthwork signatures were in terms of their elevation when viewed in the field, sometimes less than $0.1-0.2 \mathrm{~m}$ in height, and easily missed unless guided by transcribed lidar plots and a hand-held global positioning system (GPS) device. In many cases, ground-level photography as a means of recording was rendered virtually useless by the low-level earthworks. More often than not lidar data users in the archaeological community are chiefly concerned with the spatial resolution and/or point density of the lidar data they are using and less often about its vertical accuracy. In this case the high vertical accuracy of the data $(0.05 \mathrm{~m}$ at $2 \sigma(95 \%$ confidence level $))$ acquired by 
a system normally designed for very detailed applications ('engineering quality data'), such as, transmission lines, railways, levees, roads and pipelines, proved its worth in successfully delineating subtle earthwork features in an open pasture landscape that had hitherto gone unnoticed in the field by past fieldworkers relying solely on aerial photographs and/or field observation.

Beyond straightforward archaeological prospection, and the research questions arising, this lidar dataset also has a useful role to play in any future conservation-led initiatives. For example, it has been possible to identify threats (both natural and anthropogenic) to monuments and map erosion features, such as gullies and animal and vehicular wear-paths, as well as more intrusive landscape management practice, such as arterial drainage; thus highlighting the importance of this type of landscape analysis for cultural heritage management as well as wider environmental agendas (Figure 12). It is hoped that this present work will form the basis for more robust planning and management for this archaeological landscape and help guarantee its ongoing preservation.

\section{Acknowledgements}

The author is grateful to the NIEA: Built Heritage for making the Linford lidar data available, and particularly Claire Foley who directs the 'lidar survey(s) project' within NIEA; to colleagues at the Environmental Sciences Research Institute (ESRI) at the University of Ulster who commented on this manuscript prior to submission, especially Colin Breen, Wes Forsythe, Rory Quinn and Kieran Westley. Further thanks to Kieran Westley, who also assisted me greatly with the technical aspects of ALS visualizations; to Peter Horne of English Heritage for setting me straight on the sensitivities of terminology and to my former colleagues at The Discovery Programme, Anthony Corns and Rob Shaw, for first opening my eyes to the benefits of lidar for landscape survey. I would additionally like to thank Phil Macdonald of Queen's University Belfast for providing access to unpublished site plans and excavation notes relating to Knockdhu promontory. I also wish to thank two anonymous reviewers for their useful suggestions in the revision of this manuscript.

\section{References}

Barry T. 2009. Foreword. In Rural Settlement in Medieval Ireland in Light of Recent Archaeological Excavations, Corlett C, Potterton M (eds). Bray: Wordwell; VII-X.

Bennett R, Welham K, Hill RA, Ford A. 2012. A comparison of visualisation techniques for models created from airborne laser scanned data. Archaeological Prospection 19(1): 41-48. DOI: 10.1002/arp.1414
Challis K, Forlin P, Kincey M. 2011. A generic toolkit for the visualisation of archaeological features on airborne lidar elevation data. Archaeological Prospection 18(4): 279-289. DOI: 10.1002/arp.421

Corns A, Shaw R. 2009. High resolution 3-dimensional documentation of archaeological monuments and landscapes using airborne Lidar. Journal of Cultural Heritage 10 (1): e72-e77.

Corns A, Fenwick J, Shaw R. 2008. More than meets the eye. Archaeology Ireland 22(3): 34-38.

Crutchley S. 2010. The Light Fantastic: Using Airborne Lidar in Archaeological Survey. English Heritage: UK.

Crutchley S. 2013. Using lidar data - drawing on 10 year's experience at English Heritage. In Interpreting Archaeological Topography: 3D Data, Visualisation and Observation, Opitz RS, Cowley DC (eds). Occasional Publications of the Aerial Archaeology Research Group No. 5, Oxbow Books: Oxford; 136-145.

Devereux BJ, Amable GS, Crow P. 2008. Visualisation of Lidar terrain models for archaeological feature detection. Antiquity 82(316): 470-479.

Evans EE. 1940. Transhumance in Europe. Geography 25: $172-180$.

Fugro-BKS Ltd. 2009. FLI-MAP Survey: Archaeological Survey Dunluce and Linford Final Report. Fugro-BKS: Coleraine.

Gardiner M. 2012. Medieval settlement on the Garron Plateau of Northern Ireland: a preliminary report. Medieval Settlement 27: 20-28.

Hesse R. 2010. Lidar-derived local relief models - a new tool for archaeological prospection. Archaeological Prospection 17(2): 67-72. DOI: 10.1002 /arp.374

Hesse R. 2013. The changing picture of archaeological landscapes: lidar prospection over very large areas as part of a cultural heritage strategy. In Interpreting Archaeological Topography: 3D Data, Visualisation and Observation, Opitz RS, Cowley DC (eds). Occasional Publications of the Aerial Archaeology Research Group No. 5, Oxbow Books: Oxford; 171-183.

Hodges R. 1975. Knockdhu promontory fortress: an interpretation of its function in the light of some preliminary fieldwork. Ulster Journal of Archaeology 38: 19-24.

Hoyle JP. 2005. The Forest of Dean, Gloucestershire, Archaeological Survey, English Heritage Project Number 2727, Stage 2: Pilot Field Survey. Unpublished circulation draft for English Heritage, Gloucestershire County Council Archaeology Service.

Hoyle JP. 2011. Forest of Dean Archaeological Survey Stage 3B: Survey for management of lidar-detected earthworks in Forestry Commission woodland (Project Number 5291 SURV). Phase 1: Rapid field validation and scoping analysis for characterization of archaeology in woodland - Project Report Volume 1: Methodology, Results and Discussion. Unpublished report for English Heritage.

Macdonald P. 2010. Knock Dhu, Ballyhackett, Co. Antrim, Promontory Fort, summary excavation report in Monuments and Buildings Record (MBR). NIEA, Built Heritage: Belfast.

McErlean T. 1983. The Irish townland system of landscape organisation. In Landscape Archaeology in Ireland, Reeves-Smyth T, Hammond F (eds). British Archaeological Reports British Series 116: 315-340.

Nicholls K. 2003. Gaelic and Gaelicized Ireland in the Middle Ages. Lilliput Press: Dublin. 
Rathbone S. 2009. Booley houses, hafods and sheilings: a comparative study of transhumant settlements from around the Northern Basin of the Irish Sea. In Ireland and the Britain in the Atlantic World, Horning A, Brannon N (eds). Wordwell: Dublin; 111-130.

Shaw R, Corns A. 2011. High resolution Lidar specifically for archaeology: are we fully exploiting this valuable resource?. In EAC Occasional Paper No. 5, Remote
Sensing for Archaeological Heritage Management, Archaeolingua: Hungary; 77-86.

Smyth WJ. 2006. Map-making, Landscapes and Memory: A Geography of Colonial and Early Modern Ireland c. 1530-1750. Cork University Press: Ireland.

Štular B, Kokalj Z, Ostir K, Nuninger L. 2012. Visualization of lidar-derived relief models for detection of archaeological features. Journal of Archaeological Science 39(11): 3354-3360. DOI: 10.1016/j.jas.2012.05.029 